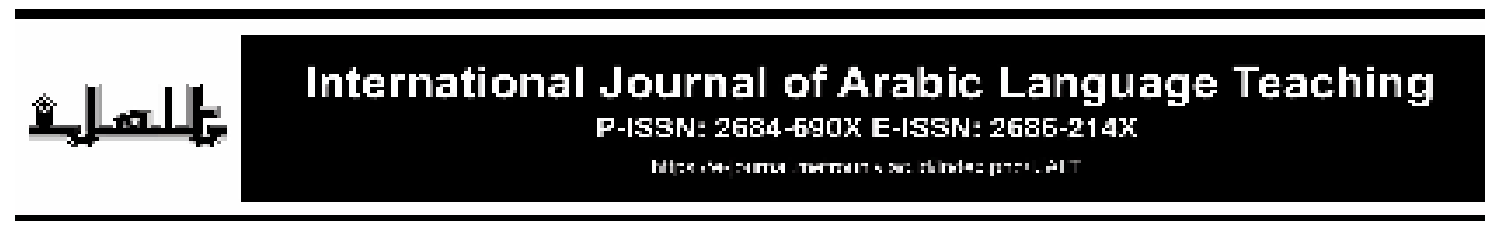

\title{
Stylistic features of Yunus Abdullahi's "Ya laimi's" Arabic praise poems to Prophet Mohammed
}

\author{
Khalil Mohammed Usman Gbodofu' ${ }^{1}$, Lawal Rahman² \\ ${ }^{12}$ University of Ilorin, Nigeria
}

\begin{abstract}
Article History:
Received : 27 September 2021

Revised : 06 December 2021

Accepted : 06 December 2021

Published : 06 December 2021
\end{abstract}

Keyword:

clarity of language; eulogies; spiritual status;

*Correspondence Address: lawalrahman@gmail.com

\begin{abstract}
Eulogizing the prophet has generated controversies among the Muslims just as this genre of poetry has been mostly ignored and seen as having no significant content. In the Islamic era the prophet permitted Hassan bn Thabit to compose poem to defend Islam and praised him. Later he condemned referring to him as Allah or son of Allah as a form praise. The aim of this study is to identify the methods used by the poet to eulogies the Prophet and describe the stylistic feature of the poem. The method of research is descriptive and analytic. The result of the study reveals that the author used three major methods to praise the prophet which include reference to his spiritual status, emphasis on his practices and tradition, and describing his religious struggle. The styles used by the author include clarity of language, use of imagery, Iqtibas (adaptation and citation of Quran verses) and rhetorical question. It is recommended therefore, that the poems should be completely translated to English for wider circulation.
\end{abstract}

\section{A. INTRODUCTION}

The praise poem is a poem with purpose. Praise is conveniently understood to a referential discourse that applifies its-referent by means of ornamental tropes and usually comparative ones. ${ }^{1}$ Praising the Prophet Muhammad peace be upon him has been a common religious literary ritual among some Islamic sects and in the introduction of many Diwan by some poets

\footnotetext{
1 Susan, S. (2016) Praise of the prophet and Praise of Self. Journal of Arabic Literature vol. 9
} (1-2_50-79. University of California: Los Angeles. 
around the globes. ${ }^{2}$ In fact, the vibrant of tradition of West African Arabic Poetry has been is dominated by the genre of Madh especially the praise of Prophet Muhammad. ${ }^{3}$

This study will examine the Arabic praise poem of Yunus Abdullah in respect of the prophet under the following sub-headings; Biography of the poets, About the poem, and Stylistic features of the poem.

He is Yunus ibn Abdullah ibn Abaukaka ibn Opochi. ${ }^{4}$ He was born in Ahatche in 1941 in Okene, Kogi State, Nigeria. ${ }^{5}$ He studied the Quran and the basics of Islamic religious studies under the tutelage of Sheikh Yahya Tajudeen al Ilori who hailed from Ilorin and then attended Ebira Comprehensive Primary from 1947 to 1955 and continued his education in Markaz Talim al Arabi al-Islami at Agege, Lagos, Nigeria where he studied for three years under the tutelage of Sheikh Adam Abudullah Al-Ilori and graduated in 1958. He joined the College of Arabic Studies in Kano in 1965 and obtained a diploma in Islamic studies in 1966. He gained admission the same year into Bayero University, Kano and obtained a Bachelor of Arts in Islamic Studies in the year 1969. ${ }^{6}$

His teachers are numerous. Those who taught him at the basic elementary Arabic school of Sheikh Yahya Tajudeen include: Sheikh Musa Abdullah, Sheikh Muhammad Rabiu Kakumi, Sheikh Abdulraheem Abdullahi, Sheikh Abdullah Idatche and Sheikh Uthman Uduka. At Markaz Ta'limil Arabi-al-Islami some of

2 Abbas, M. (2019) Analysis of the praise poem to prophet Muhammed in the Odes Khagbani, Journal of Persian Literature vol. 1.

3 Oludamini, O. (2020). Poetry in Praise of Prophet Perfection.A Study of West African Arabic Madih Poetry and Precedents. The Islamic Text and Society: UK

${ }^{4}$ Abdullahi, U (2007). UstadhYunus Abdullah. His life and Contributions in the spread of Islamic.

${ }^{5}$ Namlas (2008) Al-Maslaha Journal Biography of Justice Yunus Abdullah in Issues Affecting Islam and Muslims ISSN 1119-927X Vol. 4, 2007-2008. Impact Touch Colours Ltd: Nigeria.

${ }^{6}$ Jamiu, M. \& Alfa, M. (2012).An Analytical Study of the Elegy of Yunus Abdullah.Anyigba Journal of Arabic and Islamic Studies.A Publication of the Department of Arabic and Islamic Studies.Kogi State University.Anyigba Volume 2. 
his teachers include: Sheikh Adam Abdullahi Al-Ilori (the founder and proprietor of the school), Sheikh Yunus Sunusi, Sheikh Yunus Epe, Sheikh Yunus Zubair, Sheikh Abdul Gani Salahudeen, Sheikh Raji Sulayman and Sheikh Ibrahim alHamdu. However, his teachers in Darul-Ulum al-Arabiyah in Kano are numerous. They include: Sheikh Abdul Qadr Umar Sudani, Sheikh Sidiq Umar Sudani, Sheikh Tehran, Sheikh Abdulhakim al-Misry, Sheikh Yahya Gusau, Sheikh Husayn Adam Kazaure, Sheikh Muadh Muhammad and Sheikh Sango Daura. ${ }^{7}$

In 1947 he was appointed an assistant lecturer in Bayero University, Kano in the faculty of Arts and Islamic Studies in the Islamic Studies Unit. ${ }^{8}$ Then he was appointed a judge in the Sharia Court of Appeal, Kwara State in 1976 and he continued to act in that capacity until he was appointed the Grand Kadi (Chief Judge) of the Sharia Court of Appeal in Kogi State in 1991. He remained in that position until his retirement in 2006. He died on the second day of October, 2012 after a protracted illness at the Federal Medical Centre, Abuja at the age of $61 .{ }^{9}$

He has numerous publications some of which include: Al-Kiswatul al Manshurah, Al-Islam fi Bilad Ebira (Islam in Ebiraland), Ash-shuhur al-Islamiyah (the Islamic months), Sheikh Yahya Tajudeen, Ebira will survive, Ash-Shabab alMuslimin (the Muslim youths), Halal and Haram (the permissbles and the forbidden).

Yunus Abdullah is one of the most prolific poets and writer in Nigeria and some of his poems include: The prophetic praise, Days of the week in memory of Egypt, Tanbih al Gafilin (awakening of the forgetfuls), Elegy for Sheikh Mukhtar Gazali, Supplications to Allah, praise of Sheikh Adam Abdullahi al-Ilori, Praise of

\footnotetext{
${ }^{7}$ Abdullahi, U (2007). UstadhYunus Abdullah. His life and Contributions in the spread of Islamic.

8 Oseni, Z. I. (2000). Al-Ma'dubat-Al-AdabiyahLitullabilArabiyah Fi Ifriqiyyah al Garbiyyah. Auchi: Dar-Nur.

9 Namlas (2008) Al-Maslaha Journal Biography of Justice Yunus Abdullah in Issues Affecting Islam and Muslims ISSN 1119-927X Vol. 4, 2007-2008. Impact Touch Colours Ltd: Nigeria.
} 
Sheikh Kamaldeen Al-Adabi, Aya Ulama al-Khayri, Nun-rhymed poem in prohibition of Alcohol, praise of five erudite muslim scholars in Nigeria etc. Extramural Activities:

- Weekly Radio Broadcast - Islam calling from May 1970 - July 1971. Then Jumat talk from July 1970 until 2008.

- Fortnight Television Program on NTV, Kaduna from January 1970 - 1976 (Now NTA).

- Public Enlightenment Officer to the Pilgrims 1974/75 and 1975/76 Hajj operations on the platform of Nigerian Pilgrims Board. ${ }^{10}$

\section{About the Poem}

The title: The poem is titled "Ya Laimi" meaning "my antagonist". This title is appropriate because the author directs most of his conversations to the one who refuted the prophetic praise or celebration of the Prophet birth day. The qasidah consists of 56 line. The lines are shown below:

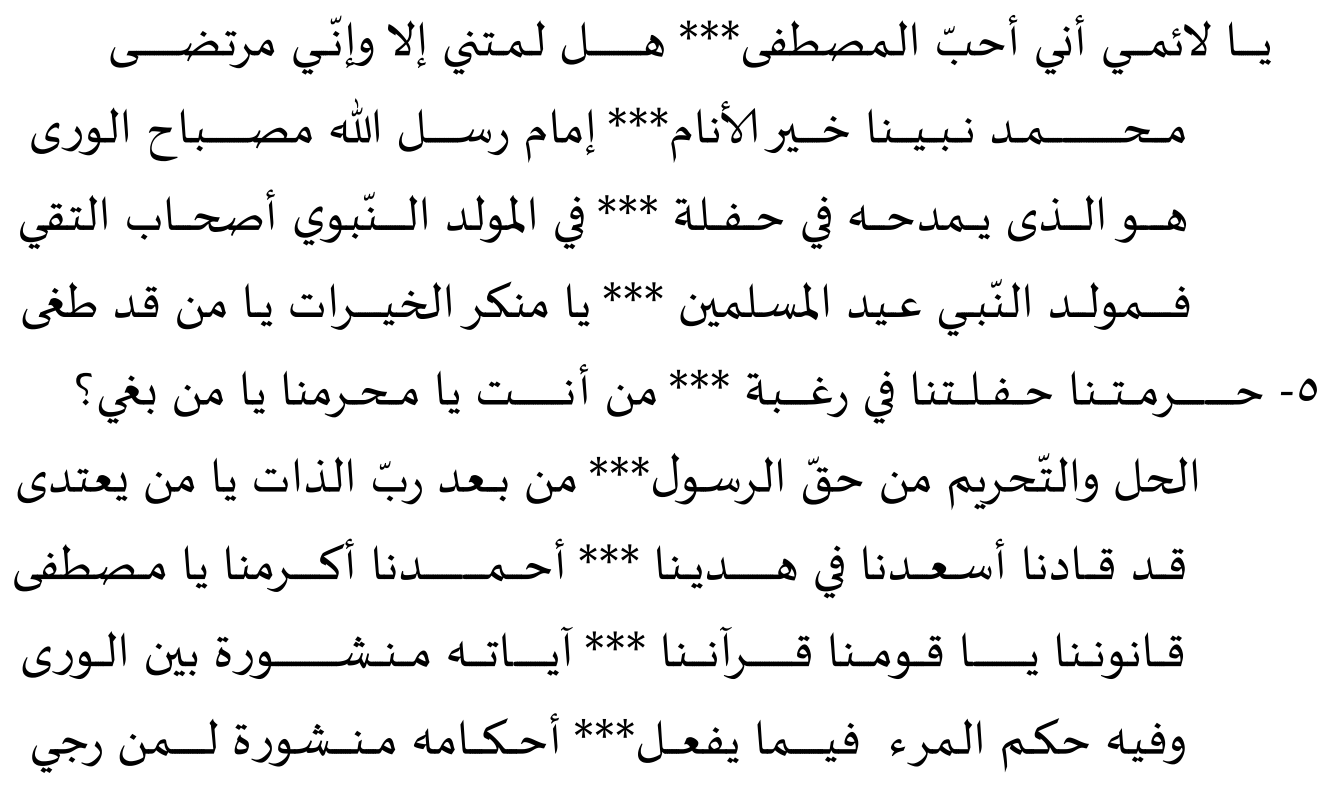

${ }^{10}$ Namlas (2008) Al-Maslaha Journal Biography of Justice Yunus Abdullah in Issues Affecting Islam and Muslims ISSN 1119-927X Vol. 4, 2007-2008. Impact Touch Colours Ltd: Nigeria. 
• ا- هـناك قـوم أخـطاؤا في دينـهم *** يا صائمسون الـدّهر قلنا قد كفى

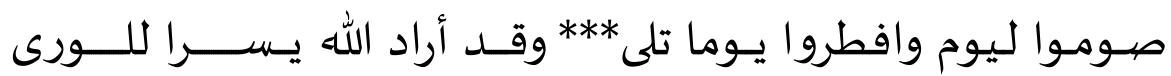

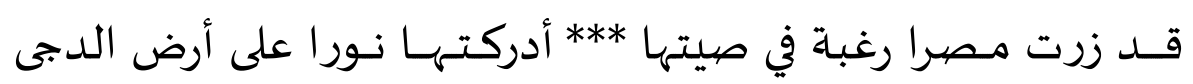

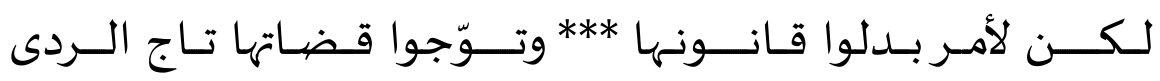

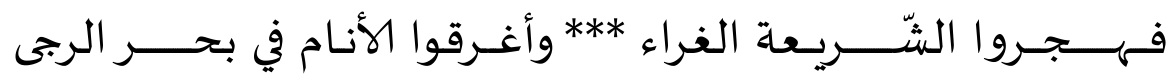

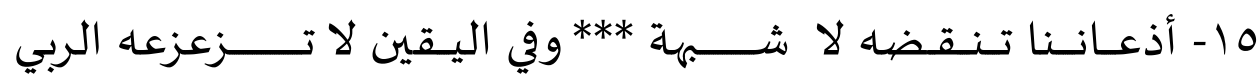

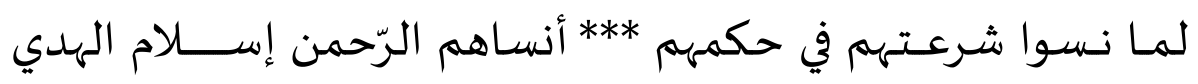

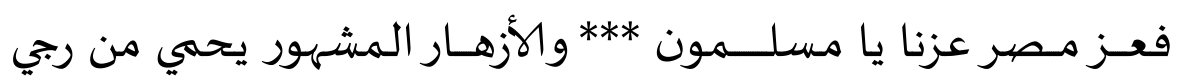

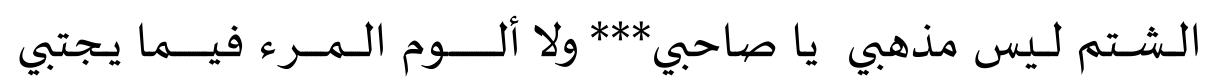

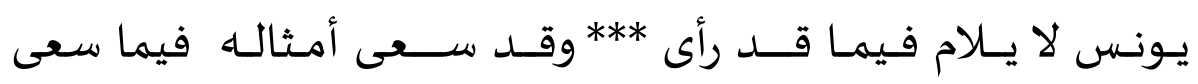

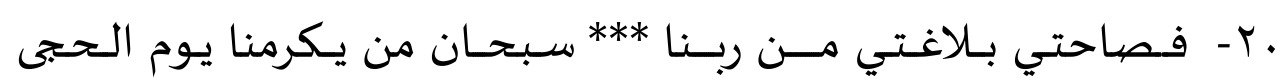

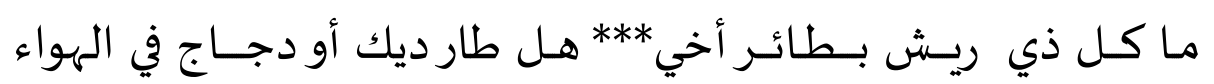

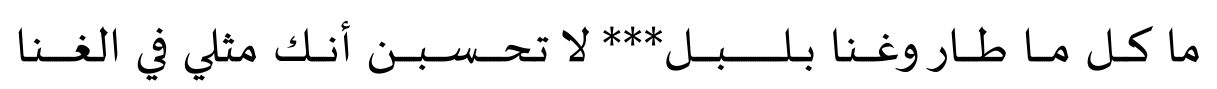

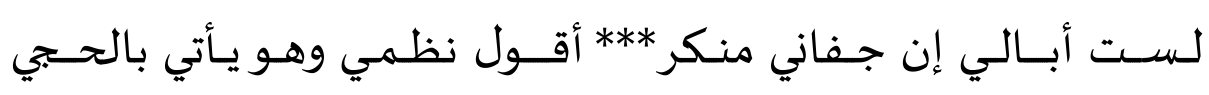

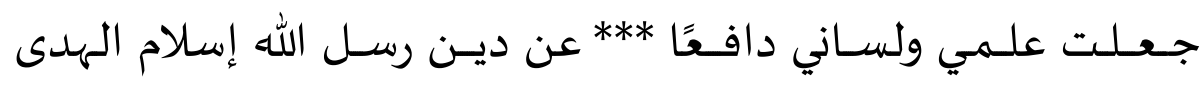

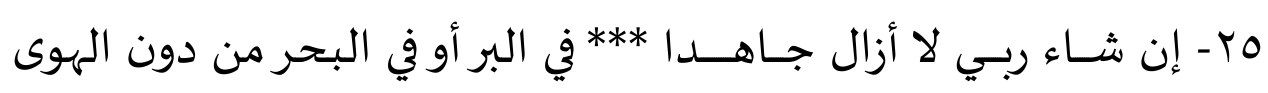

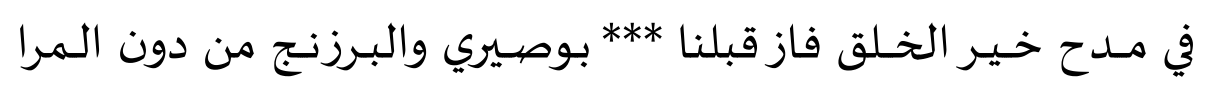

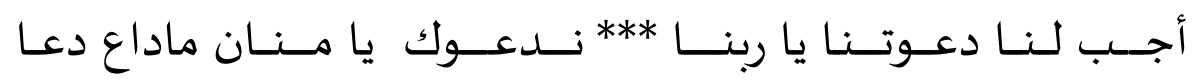

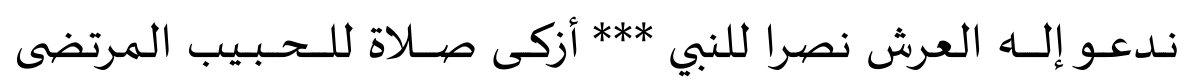

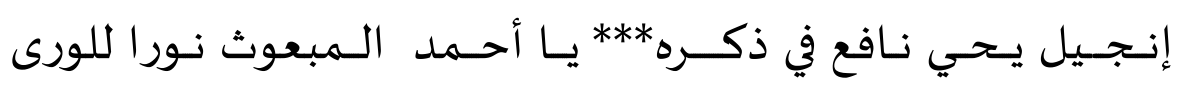

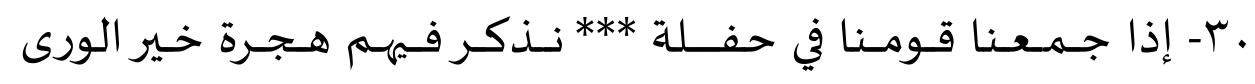

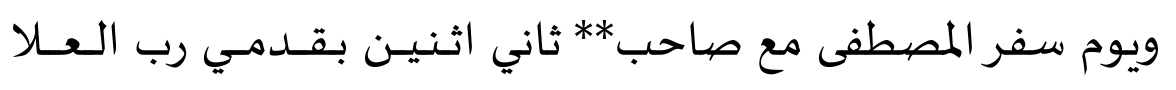

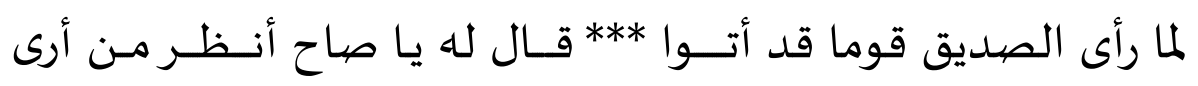

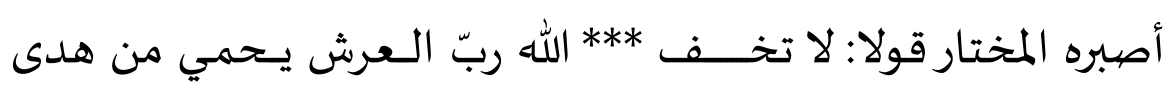


وقاهما الرحمن في الغـــاروما **** رآهــــا في الغــار إنســــان يرى

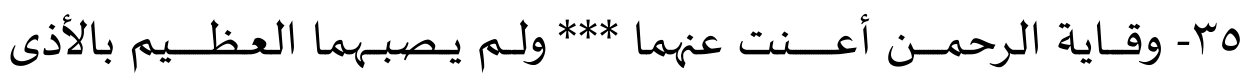

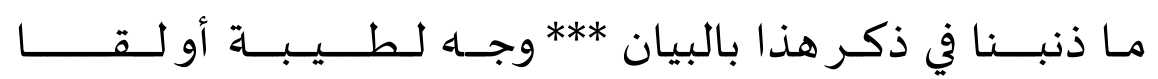

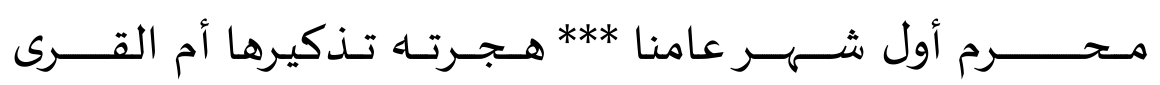

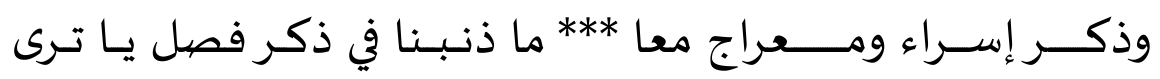

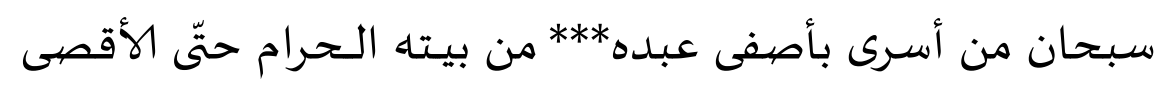

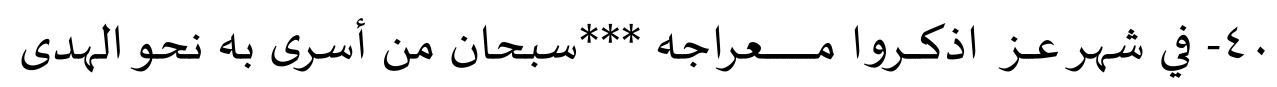

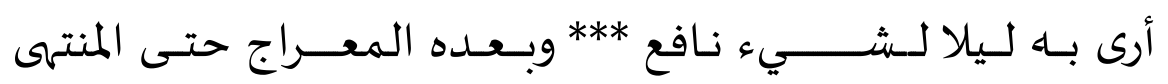

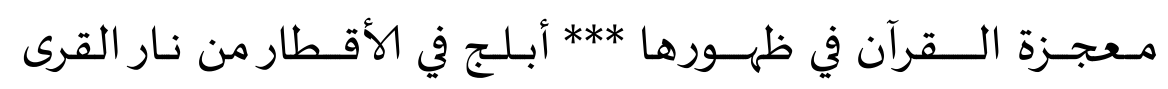

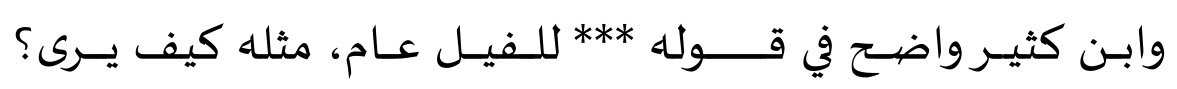

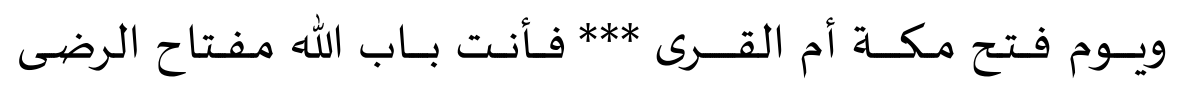

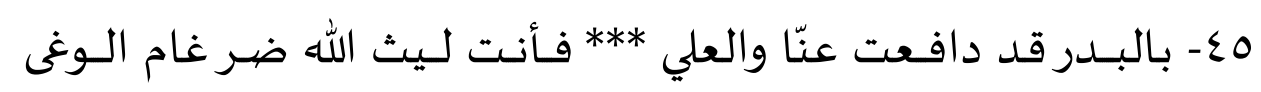

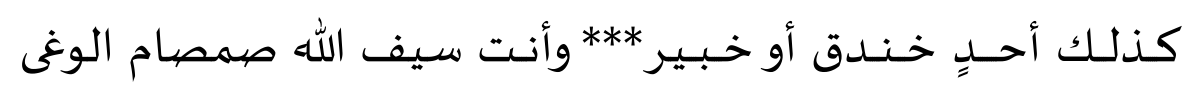

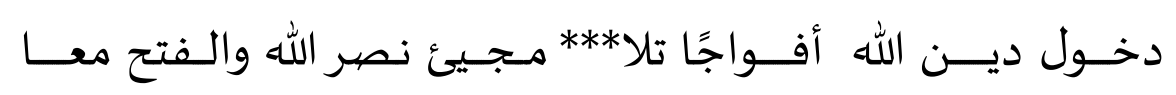

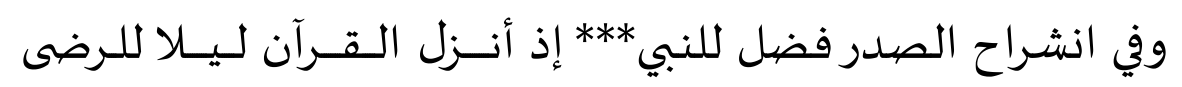

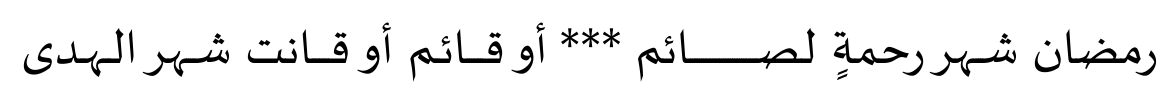

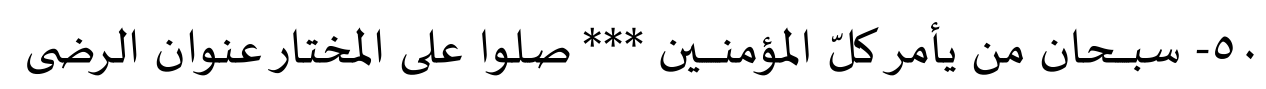

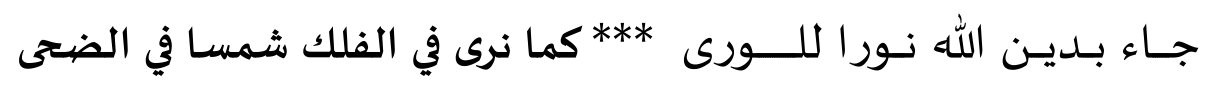

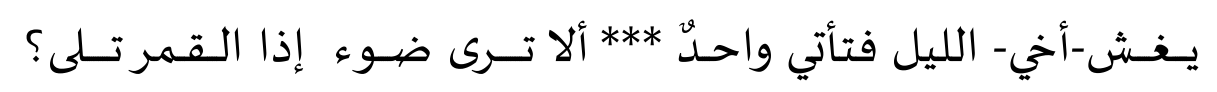

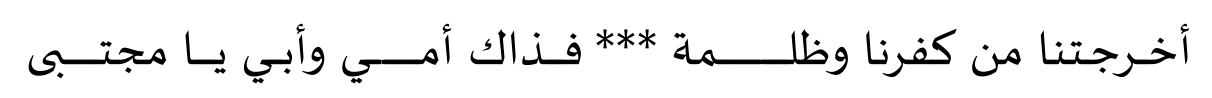

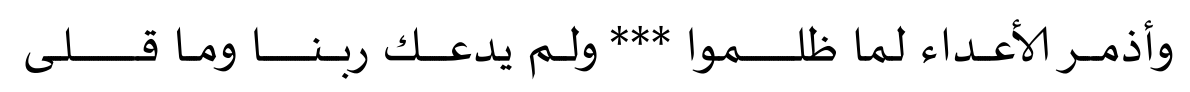

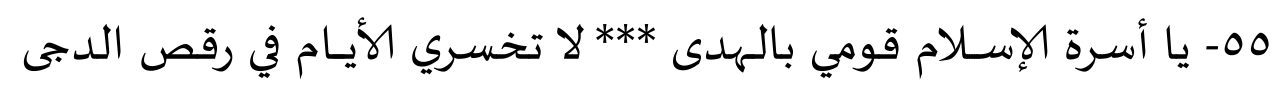

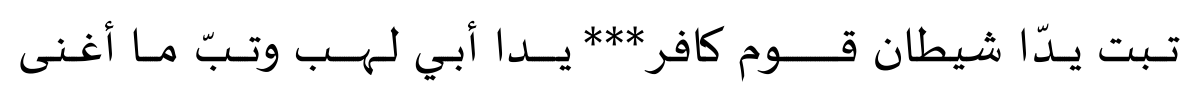


The Genre: the Genre is an Arabic praise poem to the Prophet

Sub - Themes: the following are the sub themes contained in the poem

i. Reference to the prophet's spiritual status and debunking the antagonists of praise poem to the prophet.

ii. Reference to the practices and traditions of the prophet.

iii. Reference to the religious struggles of the prophet.

\section{B. METHOD}

This study is a qualititative descriptive research. The research subjects is the poem is titled "Ya Laimi" by Poet Yunus Abdullah. The data collection technique used documentation review. Data were analyzed by applying the four steps of Creswell's version collecting data, grouping, selecting, then interpreting the data and the data source was a documents review.

\section{RESULT AND DISCUSSION}

\section{The Content}

Firstly, the author refers to the spiritual status of the prophet by referring to him as "the messenger of Allah", "Lamp of the mankind", "the best of us" "the most thankful and grateful to Allah" and the most honorable among men". Having done that the author argued that the prophet should be celebrated and praised through Mawlud nabiy (birthday) celebration. He also refuted the antagonist of the praise of the prophet and his birthday celebration requesting for evidences from them.

Secondly, the poets referred to some of the practices and traditions of the prophets which include the optional fasting especially those of the Prophet Daud, who fast for one day and break the next day. He therefore condemned those that 
fast for a year as this is contrary to the prophetic practices. He also emphasis the moderate nature of Islamic laws and refute those who failed to practice them.

Thirdly, the author made reference to the religious struggles of the prophet which include his Hijrah from Makkah to Mardina, He mentions briefly what transpires on the journey between him and Abu bakr, his close friend who accompanied him. He emphasized how Allah protected them from being seen and attacked by the enemies who went after them. He also mentions the Isra and Mi'raj (The Night journey and Ascension) where the Prophet was transported from Almasjid Al-Haram to masjid al-Aqsa from where he ascended to heaven. Infact, there were many stops along this incredible journey and thus story is packed with wonders and miracles.

\section{The Meter}

The author composed his poem using the longer form of the Razaj meter which is:

\section{Mustaf-llun Mustaf-llun Mustaf-llun}

\section{Mustaf-llun Mustaf-llun Mustaf-llun}

The poem ends in alf maksurah which serves as the rhyme (qafiyah). The aruds and darbs of most of the lines of the qasidah are not broken. There are some cases when the second silent letter were deleted.

\section{The Tone}

The tone of the poets is that of anger and love. The author expressed his annoyance to the antagonists of prophetic praise and the celebration of his birthday. He similarly showed his love for the prophet through his magnificent praise.

The Mustafi'lun become Mutafilun, some these are:

i. the line $51 \quad$ - (Ala tara)

ii. the line 52 - (Fadhaka um)

iii. the line 53 - (Wa lam yada') and 
iv. line 56 - (yada Abi)

Although the Arud of first line is not broken. The Arud (Bilmustafa) while the Darb is broken (Nimurtado).

\section{The stylistic features}

The following are some of the features of the poems

1. Clarity of language

2. Use of Imagery

3. Use of metaphor

4. Iqtibas (citation of the Quran)

5. Use of proverbs

\section{Clarity of Language}

The language used by the author is simple and clear and it does not require the use of dictionary to check meaning of words used. Some common words are used, these include rasul, mawlid, isra', miraj, madh, Ahkam and Nur etc. The qasidah also contains some general expressions and these include In shaa Rabi, Man anta? Imam-rasulillah and Muhammadun Nabiyyina etc.

\section{Use of Imagery}

The imagery of a literary work comprises the set of images that it uses which may appeal to the senses other than sight (Chris, 2021). Imagery is one of the basic subjects in the domain of aesthetic of text. Imagery in a language is used by poets, novelist and other writers to create images in the mind of the readers. Consider these examples:

'Bil Badr qad dafa'ta anna..."

Fa anta Laythul-lah...

Translation:

"At the Battle of Badr you defended us ... For you are the lion of Allah" 
In the example the visual imagery is used as the experience of the battle of Badr is described and how the Prophet fought like a lion to defend the Muslims. Another example is:

"Ja a bi dinilil-lah nurun lil'wara

Kama fi falaq shamsan fid-duha"

Translation:

"He the prophet bought the light of Islam for mankind Just like you see in the sky the sun in the morning."

In this example, the author uses imagery to describe the message brought by the prophet of Allah so the reader experiences it as he was there at the time of the beginning of revelation

\section{Use of Methaphor (Isti'arah)}

Use of metaphor (Isti'arah) is significant in the poem and the examples include:

"Fa anta laythul-lah..."

"You are the Lion of Allah..."

The author refers to the prophet as Lion. This type of comparison is significant (Istiarah Mufidah) because there is a strong relationship between the object being compared. The relationship is skill, strength and agility. The author compared the prophet to a lion during confrontation to the enemies at the battle of badr.

Another example is "......Misbah al-Wara ..."

"He is the Lamp of mankind...."

Here, the author refers to the prophet as Lamp. This type of metaphor is also significant as there is a strong relationship between the objects being compared. The relationship is guidance. Just as the lamp provide illumination to 
darkness, the prophet guides mankind from darkness of ignorance to the light of Islam.

\section{Rhetorical Question}

Rhetorical question is a question asked merely for effect with no answer expected. It is used to emphasize a point where the answer is obvious. Examples include:

Man anta ya Muharrimuna?

Meaning: Who are you to have antagonized us?

The author is expecting no answer. He is emphasizing that the one antagonizing him has no right whatsoever to do so. Another example is:

"Ma dhambuna fi dhikri mithli hadha fil bayan?"

"What is our offence for mentioning this in our lectures?"

The author is actually saying he has not committed any offence for celebrating the birthday of the prophet and discussing the Prophet during such occasions.

\section{Iqtibas}

Technically Iqtibas denotes- quotation or borrowing from the Quran or the hadith with or without explicit acknowledgement (Brill, 2008). Examples of incorporating the Quranic words by the author include

i. "Tabbat yada"

ii. 'watabba ma agna

iii. 'idhal qamaru tala

iv. Dinil-Lahi afwajan

The first two examples are borrowed from chapter 111 of the Quran. The third example is adapted from chapter 91 of the Quran which say ; "Wal-qamar idha talaha". The fourth is taken from Suratul Nasr chapter 110 verse 2 of the Quran. Other adapted words include "nasrullah" "yagshal-LayI" and "al-fil" 
An example of iqtibas from the Hadith as contained in the poem include the following:

"Sumu liyawmin wa aftiru liyawmin..."

"fast for a day and break the next day".

This is adapted from the hadith that mentioned in Sahih al-Bukhari 3238 of Abdullahi bn Amr related. Abdullahi ibn Amr reported: The messenger of Allah peace and blessings be upon him said: "verily, the most beloved fasting to Allah is the fasting of David (Daud) and the most beloved prayer to Allah is the prayer of David, upon him be peace. He would sleep a third of the night and stand in prayer for a third of it and sleep for a sixth of it and he would fast for one day and break for the following day.

\section{Use of Proverbs}

Examples of where the author use proverbs include

"Ma Kullu dhi rishin wa gana bulbulum"

Translation:

"Not all birds with wings can fly"

"Ma kullu ma tara wa gana bulbulum"

Translation:

"Not all flying birds are bulbul"

The author used the proverbs to emphasize that all statement there may be exception and that all statement are not true. Perhaps, the author is referring to the statement of his antagonist that celebration of prophet's birthday is not allowed.

\section{CONCLUSION}

This study examines the Arabic praise poem of Yunus Abdullah titled "Ya laimi" in praise of prophet Muhammad and the results of the study include

i. $\quad$ They used simple clear and straight forward language 
ii. The tone of the poem suggest an angry atmosphere where the author protest angrily against the antagonist of praising the prophet and celebration of his birthday

iii. The stylistic features of the poem involve the use of the following

- Use of imagery

- Use of metaphor

- Incorporation quranic citation

- Use of proverbs

\section{REFERENCES}

Abbas, M. (2019) Analysis of the praise poem to prophet Muhammed in the Odes Khagbani, Journal of Persian Literature vol. 1.

Susan, S. (2016) Praise of the prophet and Praise of Self. Journal of Arabic Literature vol. 9 (1-2_50-79. University of California: Los Angeles.

Jamiu, M. \& Alfa, M. (2012). An Analytical Study of the Elegy of Yunus Abdullah. Anyigba Journal of Arabic and Islamic Studies. A Publication of the Department of Arabic and Islamic Studies. Kogi State University. Anyigba Volume 2.

Oludamini, O. (2020). Poetry in Praise of Prophet Perfection. A Study of West African Arabic Madih Poetry and Precedents. The Islamic Text and Society: UK

Brill, R. (2021). Encyclopedia of Islam. The Iqtibas. Retrieved from http:// referenceworks.brillonline.com on 24/6/2021

Namlas (2008) Al-Maslaha Journal Biography of Justice Yunus Abdullah in Issues Affecting Islam and Muslims ISSN 1119-927X Vol. 4, 2007-2008. Impact Touch Colours Ltd: Nigeria.

Bello, I. A (2018). The Contributions of Yunus Abdullahi to Islamic activities in Ebiraland. An unpublished M. A. Thesis submitted to the department of Arabic and Islamic Studies. Kogi State University, Nigeria. 
Oseni, Z. I. (2000). Al-Ma'dubat-Al-Adabiyah Litullabil Arabiyah Fi Ifriqiyyah al Garbiyyah. Auchi: Dar-Nur.

Chris, B. (2021). The Concise Dictionarry of Literary Terms. Macmillian Publishers Ltd: Oxford.

Allen, J. (2000) Literature MC Dougal Littel Publication. Boston - Dallas.

Abdullahi, U (2007). Ustadh Yunus Abdullah. His life and Contributions in the spread of Islamic Civilization in Ebiraland. A B.A. Project submitted to Department of Arabic language, Bayero University, Kano. 